\title{
Sola Scriptura and Its Impact on Christian Prophetic Making in Nigeria: Its Ambivalence
}

\section{Nmah, Patrick Enoch}

\author{
Department of Religion and Human Relations, Nnamdi Azikiwe University, Awka-Nigeria \\ Email: patricknmah@yahoo.com
}

\author{
Doi:10.5901/mjss.2016.v7n2s1p104
}

\begin{abstract}
The objective of this paper is to critically study the problems posed by the doctrine of sola scriptura and its impact on Christian prophetic making in Nigeria. It is discovered that the application of the sola scriptura as part of Christian beliefs and practices galvanized the emergence of new religious movements in Nigeria. The major implication of the doctrine of sola scriptura resides mainly in the fact that the human interpretation and application of the scriptures do not hold the same authority as the scriptures themselves. This study adopted historical and descriptive approaches of interpretation in respect of sola scriptura. It employed also the use of primary and secondary sources.
\end{abstract}

Keywords: Sola scriptura, Ambivalence, Prophecy, Christianity, Nigeria, Prophetic Christianity

\section{Introduction}

Over time, the Christian faith, its principles and practices have mostly been dependent on and largely led by the prescriptions of the Bible, often referred to as the Holy Scriptures. Together with other monotheistic religions such as Judaism, and Islam, Christianity has usually been regarded as the "People of the Book". Although the "Catholic Church rejects similar expression "Religion of the Book" as a description of the Christian faith, preferring rather the term "religion of the word of God", since the faith of Christ, according to Catholic teaching, is not found or anchored solely in the Christian scriptures, but also in the sacred tradition and magisterium of the Church. The Roman Catholics were of the view that the Church alone is authorized to translate and interpret the Bible; and, since it is already in the universal language (that is, Latin), there is absolutely no reason to translate it further. This is to protect it from reaching a false interpretation. Nevertheless, it is evident that almost all Christians believe and hold the doctrine of the inspiration, clarity and authenticity of the scriptures. The divergence of opinion, persuasion and belief regarding the scriptures among the various Christian denominations is, however, prominent in reference to its sufficiency for human salvation, and its position and authority in relation to other vital elements of Christian doctrines and practices such as tradition and reason.

Obviously, most Protestants of the Reformation background hold the doctrine of sola scriptura, which is a Latin expression of "scripture alone", teaches that the Bible is the supreme authority in all matters of doctrine and practice. Hence all things about human salvation and Christian conduct are to be examined and judged by the scripture. However, others like the Anglicans and Methodists uphold almost in complete agreement a similar concept of "prima scriptura," which teaches that sacred scripture is illumined by tradition, reason, and in Methodism, experience as well, thereby, completing the four sides of the Wesleyan Quadrilateral". But these are subject to and are examined by scriptures. Any tradition, reason or experience that seems to be contradictory to the scriptures is viewed not to be valid.

In contrast, the primary Catholic argument against sola scriptura is that the Bible does not explicitly teach sola scriptura. Catholics argue that the Bible nowhere states that it is the only authoritative guide for belief and practice. Hence, according to the Catholics, ecclesiastical authority and tradition give interpretation to the scripture and not the reverse. Nevertheless, in reference to the supremacy of the scriptures in matters of faith, Luther was cited to have said that, "a simple layman armed with the scripture is greater than the mightiest Pope without it".

The major implication of the doctrine of sola scriptura resides mainly in the fact that the human interpretation and application of the scriptures do not hold the same authority as the scriptures themselves. Thus, even ecclesiastical authority, tradition and reason, are viewed as subject to, and can be corrected by the scriptures. Interestingly, most Protestants, especially Lutheranism, insist that "the Bible of the Old and New Testaments" is the only divinely inspired book and the only source of divinely revealed knowledge. Scripture alone is the formal principle of the faith in Lutheranism, the final authority for all matters of faith and morals, because of its inspiration, authority, clarity, efficacy, and sufficiency". In this research therefore, the phenomenological approach was employed to examine the impact of the 
principle of sola scriptura in the Christian prophetic making in Nigeria so as to ascertain its reliability, relevance and viability in a grossly religious competitive Nigerian community.

The significance of this study basically stems from the fact that it addresses the issues that threatened the collective existence of Christian communities, and offers a valid and insightful resource material those future scholars especially church historians can consult to gain useful information on the Christian prophetic making in Nigeria.

\title{
2. Understanding the Concepts
}

It would presumptuous to embark on this research work without proper understanding of the major operational terms involved in our study. In this regard, terms such as sola scriptura, prophetic Nigerian Christianity and Nigeria are briefly examined in relation to the imports of this paper.

Sola scriptura: As earlier observed, it is a Latin ablative which means by "scripture alone". It is a Protestant Christian doctrine which states that the Bible is the supreme authority in all matters of doctrine and practice. According to the Wikipedia Free Encyclopedia, sola scriptura basically means that all things necessary for salvation and concerning faith and the spiritual life are taught in the Bible, and clear enough for the ordinary believer to understand it.

While this principle does not deny that other authorities govern Christian life and devotion, it sees them all as subordinate to and corrected by the written word of God. It belongs to the five Solae of the Protestant Reformation, which include sola fide, sola gratia, sola scriptura, solus Christus, and soli Deo gloria. Sola scriptura, however, holds that the word of God is the only authority for the Christian faith. Traditions are valid only when they are based on the scripture and are in full agreement with the scripture. Traditions that contradict the Bible are not of God and are not a valid aspect of the Christian faith. Sola scriptura is the only way to avoid subjectivity and keep personal opinion from taking priority over the teachings of the Bible. Grudem (1994) cited the Chicago Statement on Biblical Inerrancy by saying;

\begin{abstract}
We affirm that the Holy Scriptures are to be received as the authoritative word of God. We deny that the scriptures receive their authority from the Church tradition or any other human source. We affirm that the scriptures are supreme written norms by which God binds the conscience, and the authority of the Church is subordinate to that of the scripture. We deny that the Church, creeds, councils or declarations have authority than or equal to the authority of the Bible (p.1204).
\end{abstract}

The doctrine of sola scriptura is a presupposition for the revelation, inspiration, infallibility, and inerrancy of the scriptures. While it is obvious that the inspiration and revelation of the scripture are almost generally accepted among the various Christian groups and Church denominations, it is the principle of the canonization and authority of the Bible that mostly set the Churches, especially the Protestants and the Roman Catholics, apart. The doctrine of inspiration of the scripture is, however, immensely important because most of other evangelical doctrines are developed from the Bible. They rest upon and find their relevance and authority on the scriptures. Harrison (1985) cited L. Boettner (1947) and said that the biblical teaching of inspiration is the "mother and guardian of all others", including the sola scriptura. According to him,

\footnotetext{
An unsound view of the inspiration of the scripture is bound to countenance unsound views, produce distorted teachings or serious gaps in essential doctrinal systematization or offer a temptation to easy subscription to plausible but unsound scientific or philosophic theorizing (p. 620).
}

The fact of Biblical inspiration is clearly stated in 2Tim. 3:16-17, "All scripture is inspired by God and is profitable for reproof, for correction, for training in righteousness; that the man of God may be complete, equipped for every good work". In view of this, Packer in Ferguson and Wright (1988) says that scripture mediates the authority of God who gave it and the Christ to whom it testifies, and it does this by presenting the realities of salvation-history in their universal significance. According to him, the issue is the nature and extent of the control that canonical scripture should exercise over the doctrine, discipline and devotion of the Church and its members (p. 630).

Geisler and MacKenzie (2009) particularly state that sola scriptura among Protestants means that scripture alone is the primary and absolute the source for all doctrine and practice (faith and morals). It implies that the Bible is a direct revelation from God; it is sufficient, and divinely authoritative. Thus, what the Bible says, God says. In this sense the scriptures do not just contain the word of God, but in its entirety is the word of God. Sola scriptura is a Reformation slogan which asserts that scripture is the Church's only infallible and sufficient rule for deciding issues of faith and practices that involve doctrines. While the Bible does not contain all knowledge, it does contain that which is necessary for salvation. Indeed, if something is not found in scripture, it is not binding upon the believer. This view does not deny 
that the Church has the authority to teach God's word, nor did the Reformers reject everything that every Christian in earlier ages has said. Furthermore, while tradition is valuable, it but must be tested by the higher authority of the scriptures. Given this understanding, the position, role and impact of the scriptures become a critical issue that deserves thorough examination especially with clear perception on prophecy and 'prophetic' in contemporary Nigerian Christianity.

Prophecy: This has often been associated with the foretelling or prediction of what is to come. It is something that is declared by a prophet, especially a divinely inspired prediction, instruction, or exhortation, a divinely inspired utterance or revelation. According to the Wikipedia Free Encyclopedia, prophecy involves a process in which one or more messages allegedly communicated to a prophet are then communicated to other people. Such messages typically involve divine inspiration, interpretation, or revelation of events to come.

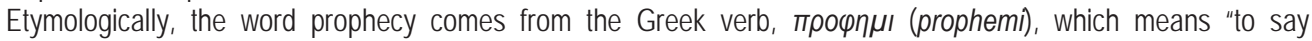
beforehand, or to foretell". It is a combination of the Greek words, про and $\varphi \eta \mu \mathrm{s}$. The Greek prefix про also means "before," "in front of," so трофпu means to speak in front of, as a spokesperson. Nmah (2009) noted that "a prophet" is called. In fact it is the experience of his call and mandate that are most characteristic of him. He is not a politician, a social thinker, a philosopher nor a poet even though his sayings are in poetical form" (p.18). According to him, the prophet entirely belongs to his God. He is the one speaks for another (Ex. 7:1f, Deut. 18:18). His office presupposes people's ignorance and blindness with respect to God's will and purpose, which the prophet as spokesman of the Almighty seeks to dispel.

Harrison (1985) said that the predictive element was a frequent part of the content of the prophet's message. But this is not the only element. Though as earlier noted, the prophet is not a politician, but prophets frequently appeared in the role of social and political reformers, stirring preachers of righteousness and religious revivalists in addition to being predictors of judgment or blessing as the occasion demanded. The prophet's message was ever "religious and spiritual, announcing the will of God to and calling for complete obedience" (p.1039). Evidently, the scripture presents prophetic prediction as a manifestation of God's power glorifying his person, exalting his redemptive work in Christ and setting forth the divine character of his revealed and written word which is the scripture.

Nmah's treatment on the personality of the prophet in reference to his prophetic functions is worth examining. He said that,

The life of a prophet is characterized by a personal communion with God in prayer, devotion, meditation and moral submission to the divine will. What distinguishes a prophet from all other religious men and women is that he never keeps his religious experiences to himself. He feels compelled to announce it to others (p.18).

In this regard, this paper agrees that a prophet does not live for himself nor use the scripture for his personal advantages, but is usually under obligation to declare the revealed word of God; the message of his master, not his own, since he is simply a messenger. Thus, "he knows no other rules than the force and guidance of divine impulse". Although the idea of the prophet "losing his freedom as an ordinary man and is forced to follow the orders of his God" tend to depict a picture of a 'helpless robot'. It is agreeable that one major characteristics of a prophet is a 'feeling of being under a superhuman and supernatural' influence, including "the experience of extrasensory perceptions" such as dreams, visions, and predictions and so on. In any case there are prophets, who are regarded as false prophets, because they have no sense of divine mandate, supernatural influence and direct message from the Almighty or they have lost them all together. It is against this backdrop that the re-examination of Christian prophetic making in Nigeria and its relationship with the unchanging word of God, and the scripture becomes expedient.

The New Testament understanding of prophecy is similar, though may not always possess the cultic dimensions in some Old Testament prophetic ministry. Nmah (2009) notes that,

In the Christian New Testament, prophecy is referred to as one of the spiritual gifts that accompany the indwelling of the Holy Spirit. From this, many Christians believe that prophecy is the supernatural ability to receive and convey a message from God or the divine. The purpose of the message may be "edifying, exhorting and comforting" the members of the Church or an individual believer. In this context, not all prophecies contain predictions about the future (p.22).

The unfolding encounters with Jesus' ministry in the New Testament revealed that he was severally referred to as a prophet. For instance, after relating the true details of her past life, the Samaritan woman in John 4:19, declared of Jesus, "I can see you are a prophet". Apart from this, Jesus constantly made predictive assertions of things to come, especially with regard to his discourses on the "Son of Man and the Kingdom of God".

Nevertheless, prophetic ministry in the New Testament is not exclusively predictive in nature, it also possess 
cognitive teaching dimension. Hence, in Acts 13:1, the Church in Antioch was said to have prophets alongside with teachers. Therefore, the Apostle Paul also mentions Prophets to be among the fivefold ministries of the Church, which include others such as apostles, evangelists, pastors and teachers (Eph. 4:11). The creepy-crawly issue with regard to prophetic Christianity is not its authenticity, availability or its practicability in the scripture, but its valid applicability in the contemporary Christianity of the Nigerian situation. A brief survey of the context of our scope of study will therefore suffice for understanding the impact of sola scriptura in the making of prophetic Christianity.

Nigeria is a socio-political entity situated on the Southern coast of West Africa, sharing borders with Benin Republic to the west, Cameroun and Chad to the east and Niger to the North. It is bordered to the south by the Atlantic Ocean. It covers a sprawling area of 923, 733 square kilometers, and has the largest population in Africa, estimated to be between 160 and 170 million people. Although, there is a widespread notion that Nigeria is equally divided between two major religions-Christianity and Islam; their population ratio is a highly contentious issue. Apart from the internal population estimate which includes adherents of Traditional Religion, Stefanos (2009) observes that "Nigeria's population includes both more Christians in any other African State and more Muslims than in any other African State too. It is estimated that one out every six Africans, is a Nigerian.

Importantly, it is notable that before the advent of Christianity in Nigeria, there were personalities who functioned under superhuman and supernatural influences as seers, diviners, medicine-men in African traditional religious settings. Onunwa (1990) observed that,

\begin{abstract}
Prophets occupy important position in African traditional religion just as priests. Prophets had appeared in the past particularly in circumstances of social stress. Since the history of the traditional religion has not been written, it has not been possible to record the development and rules of the prophetic ministry in the faith. A reconstruction of the ministry of prophecy in the traditional religion may not necessarily fit into the biblical or Islamic concepts and understanding of prophecy (p.58).
\end{abstract}

Since the African understanding of prophecy is principled on oral tradition and unwritten, and do not necessarily fit into the scriptural concept, a re-interpretation of the concept of prophecy from the standpoint of the Protestant doctrinal concept of sola scriptura is therefore pertinent.

\title{
3. Biblical Hermeneutics and Christian Prophetic Making in Nigeria
}

Although the principle of sola scriptura seems to focus basically on the authority of the scripture, the interpretive of the Bible in relation to the wholistic ministry of the Church especially Christian prophetic making in Nigeria holds crucial significances. Silva (1996) thus said that "the truth of scriptural authority does not automatically tell us what a given passage means; it does assure that, once we have correctly identified the biblical teaching (in other words, proper interpretation is assumed), that teaching may be trusted unequivocally" (p.19). Generally, according to Hazelton in Ferguson and Wright (1990), "Hermeneutics concerns not only the interpretation of texts; but on the interpretation and understanding of any act of communication, whether written or oral, verbal or non-verbal (such as symbols or symbolic acts)" (p.293). Biblical hermeneutics therefore is a specific area which focuses on the study of the principles of interpretation concerning the books of the Bible. It involves the interpretation, understanding and appropriation of biblical texts.

The emphasis on biblical hermeneutics is the profound reflection on the very basis and purpose of interpretation and of how we decide what would be considered as correct interpretation. When there is difficulty in understanding an unclear text of scripture, recourse is made to other biblical texts. For the Bible is the best interpreter of the Bible. In the scriptures, clear texts are used to interpret the unclear ones. Maintaining that scripture interprets scripture, therefore, this concept is known as the analogy of faith principle.

The prophet does not and is not expected to declare his own self-initiated message, but that of his master using the word of God under the supernatural mandate and the influence of the spirit of God. His communicative formula is nothing short of "Thus says the Lord". It is clear then that the written word of God which is believed to be inspired or Godbreathed, infallible and authentic, should be the basis and only guiding principle for his prophetic utterances, which in turn constitute his doctrines, life style and his practices. The Apostle Peter spoke succinctly of this and said, "For prophecy never had its origin in the human will, but prophets, though human, spoke from God as they were carried along by the Holy Spirit" (1 Peter 1: 21). The Berean Study Bible puts it clearer thus, "For no prophecy was ever brought about through human initiative, but men spoke from God as they were moved by the Holy Spirit".

From the above biblical quotation, it is obvious that prophecy and Christian prophetic making in Nigeria is uniquely 
tied to the Word of God. As part of her discourse on the "13 keys to receive and release a prophetic word", Michelle Mclain (2015) says that,

\begin{abstract}
All of the Lord's words, no matter in what form we hear them, must be quickened and revealed by the Holy Spirit. Quicken means "adding life to ordinary words." The Greek word for quicken means "to make alive and give life by spiritual power to arouse and invigorate." The word Jesus speaks has life and vitality. Other words are just dead language. The message can come in a variety of ways-flashes of pictures, scriptural verses, sentence fragments or impressions (p. 23).
\end{abstract}

However, the Wikipedia Free Encyclopedia states that in his forward to R. C. Sproul's Knowing Scripture, J. I. Packer observes that Protestant theologians are in conflict about biblical interpretation. To illustrate the diversity of biblical interpretations, Yarchin (2004) pictures a shelf full of religious books saying different things, but all claiming to be faithful interpretations of the Bible (p. x). Furthermore, Ramm (1970) observed that such diverse interpretations underlie the "doctrinal variations in Christendom." The absence of hermeneutics or misunderstanding of it feeds the Charismatic movements in Nigeria. Pentecostals and Charismatic tend to base much of their teachings on poor principles of Bible interpretation. A mid-19th century book on biblical interpretation observed that even those who believe the Bible to be "the word of God" hold "the most discordant views" about fundamental doctrines" (p.3).

In a paper titled "Pentecostal Experience and Hermeneutics", Stronstad (2015) states that,

The Bible is the written record of God's past revelation. Nevertheless, the interpreter experiences it not merely as a historical document, but as a contemporary word from God to us. The understanding of this historical-contemporary word, then, involves both cognitive and experiential presuppositions; that is, the understanding of the Bible is as much pectoral as it is cerebral. On the one hand, the cognitive dimension is necessary in order that the interpreter may understand languages that are not his own, cultures that are radically different from his culture, and the history of other peoples that is not his history. On the other hand, whereas experience can never be the basis of theology, experience is the contemporizing of history. Thus, the understanding of the Bible generally involves a hermeneutical cycle (p. 11).

The unique Biblical interpretative approach by several Protestants, and Pentecostals in Nigeria ( for instance, Assemblies of God Church, Methodist Church Nigeria, Church of Nigeria, Anglican Communion, Redeemed Christian Church, Triumphant Rock Assembly, New Creation Bible Church, Household of God Fellowship, Power-line Bible Church, Christ Chapel, Grace of God Mission, Cherubim and Seraphim, Church of God Mission, Deeper Life Bible Church, Mountain of Fire and Miracles Ministries in particular, would be helpful to decipher the divergences and particularities often associated with the various understandings concerning the principle of sola scriptura. For instance, Strnstad (2015) insists that "the experience of the divine by God's people in the past addresses the experience of God's people in the present, and the present experience of the divine informs the understanding of the past. In this way the divine word as a historical document becomes a living word-a word that, like God himself, is, was, and is to come. Thus, the record of the past historicizes experience, and the present encounter with that record contemporizes history.

On the other hand, it might be necessary to admit Anderson's (2015) view that "the Pentecostal method of interpretation is essentially pneumatic or charismatic. This is to say that the interpreter relies on illumination by the Holy Spirit in order to come to the fullest comprehension of the significance of the text. According to him, Pentecostals uniquely use the various genres in the Bible (the historical narratives, in particular), and that they incorporate church history, personal experiences, theological biases, and other elements in their hermeneutics. The advances they are making are achieved by articulating just how these elements influence them and how they treat them when they interpret the Bible.

\title{
4. Critical Analysis of Sola Scriptura and Prophetic Christianity
}

Against the backdrop of these differences of interpretation among the various Christian traditions, even within the Protestant circles, there have arisen several divergent and often wrong interpretations, appropriation and application of biblical texts, resulting in obvious deviation from the concept of sola scriptura. No interpreter of the scripture which is the word of God is expected to impose his own meaning to the content of its message. When God gives a prophetic word, he also gives instructions about how it should be delivered. Prophets must make sure that they get his instructions and act on them. A word that is delivered in an incorrect way is nullified, and effectively becomes a false prophecy. Evidently, false and fake prophetic Christianity in Nigeria has become the bane of our society. Thus, Onyeidu (2004) cited Agumuo as saying that, 
Churches are everywhere. Men and women are competing vigorously to plant many more. . . Go to the Bar beach, Bible clutching men and women are there prophesying. Visit River banks in villages, they are there in flowing white green, or yellow gowns (p.57).

It is doubtless therefore, that the individualistic approach and freedom to biblical interpretation especially among the Protestants have given rise not only to wrong interpretation of the scripture based on personal perceptions, but also to schism and proliferation of churches in Nigeria. Nmah (2008) identified this as part of the socio-religious factors leading to proliferation of churches. According to him, it is characterized by new doctrine, liturgy, and new political structure. Other factors include false prophesy, personality clash, clamour for miracles, signs and wonders, false religious experience, religious fanaticism, cum others.

The clamour for miracles, signs and wonders and the quest for the power of their manifestations are rampant. The biting economic conditions and ghetto mentality of miracle seekers in Nigeria have provided advantage grounds for the thriving of false Christian prophetic making in Nigeria. The unsuspecting victims are often convinced that these prophets are using the scriptures, which is the word of God. Incidentally, the havoc of false prophecy is not confined to the poor, the sick and the needy, but also to the elites and politicians who fall prey to these false and wrong interpreters of the scriptures.

Oladejo (2015) in an article titled, "Nigerian Presidential Election and the Shame of False Prophets" averred,

To refresh our memory, the electioneering period was a time these fake prophets multiplied like swarm of flies. The politicians bent on winning at all cost courted them. Like father, like son, these prophets as true scions of their great grandfather Balaam, that prophet known to prophesy at the smell of filthy lucre, went over themselves to say not what God sent them to say but what their clients were eager to hear. They forgot to learn from the calamity that befell ministries of fake prophets in our recent history (p. 13).

Unfortunately, according to Oladejo, the outcome of the election had shamefully proved that many of these prophets never got their boastful pronouncements from God in the first place. While political parties in the election, winners and losers alike can point to their contributions to the deepening of democracy in the country, the hordes of false prophets were completely put to shame. They are nothing but too for penny false prophets. The reason for this ugly development in Nigeria is not far-fetched; the principle of sola scriptura is set aside in many instances in the practice of prophetic Christianity.

Ugwu (2015) reacting to this obvious deviation from biblical heritage says, "It is important to highlight that a lot of people pursue the things of this life as if that is the ultimate things in life". According to him,

It is widely believed by biblical naïve people that material acquisition is an eloquent expression of greatness and a proof that God is with someone. In as much as material things are not bad per se, and having them in a modest way is gainful, having them alone without Christ is simply a show incredible emptiness. Therefore when one encounters Christ and engages in an enduring relationship with Christ, a lofty height would be attained according to God's schedule (p.5).

Often, the major culprits of the error of deviation from the correct interpretation of the scriptures are usually Pentecostals who mostly employ literalism as their main interpretative approach to the Bible. According to the Encyclopedia Britannica,

Literal interpretation asserts that a biblical text is to be interpreted according to the "plain meaning" conveyed by its grammatical construction and historical context. The literal meaning is held to correspond to the intention of the authors. This type of hermeneutics is often, but not necessarily, associated with belief in the verbal inspiration of the Bible (p. 1205).

In this regard, Gordon Fee as cited by MacArthur (2015), states that the attitude of the Pentecostals toward scripture regularly has included a general disregard for a scientific exegesis and carefully thought out hermeneutics. In fact, hermeneutics has simply not been a Pentecostal thing. Scripture is the word of God and is to be obeyed. In place of scientific hermeneutics, there developed a kind of pragmatic hermeneutics. Obey what should be taken literally. Spiritualize, allegorize, or emotionalize the rest. They spin the Bible at random looking for something that might seem applicable to whatever trial or need, they or their clients are facing.

The story of one Bishop Kayode Peller in the Sun Newspaper of September 5, 2015 who confessed selling his son, using him as collateral in order to obtain cocaine is very revealing. Although the said Bishop confessed that this took place before his conversion to Christianity, but the fact that he was an internationally acclaimed professional magician (a 
trade he inherited from his father), who turned to a Pentecostal Bishop leaves so much to be imagined especially for a speculative or even an objective thinker. While this paper does not intend to investigate or judge Bishop Peller, the issue of the genuineness of his call and the truthfulness of his practice in Christian prophetic making in Nigeria leaves many questions to be answered, given his background in magic, occultism and Islam.

Apart from these deviations, the principle of sola scriptura has provided necessary logical deductions to conclude that what is written and contained in the scripture is the only infallible basis for faith and practice; and that they are sufficient, without tradition or any other aid, for human salvation. The fact that the scripture is believed to be Godbreathed and by it Christian believers are 'equipped for every good work' (2Tim. 3:16-17), it provides the basis and final authority for the practice of Christian prophetic making in Nigeria. This understanding has been profitable for guiding the beliefs and practices, especially of the orthodox Protestants, and also for regulating the excesses of some practitioners of prophetic Christianity.

In view of this, however, it is observed that while some practitioners of prophetic Christianity in Nigeria have obviously deviated from the concept of sola scriptura, thereby making merchandise of the practice (cf. 2Chronicles 18:1ff), a few others while remaining committed to the concept, are assuming not only religious but also strong sociopolitical voices in Nigeria. In a Newspaper report of September 7, The Nation (2015) captured the message by Prophet Oladipupo Funmilade titled "The need to rescue Nigeria". According to the report, the Prophet said that, "If all the negatives touching Nigeria are to be tackled, then every one of us must have the fear of God and be righteous". His bold assertiveness in referring to the present Nigerian government is characteristic of Old Testament biblical prophets, and commendable. The Prophet Oladipupo further said,

\begin{abstract}
Things are not as expected in Nigeria now, and we (Nigerians) expect much from President Buhari's government and the truth is that he (Buhari) cannot do it alone, everybody must be involved. The truth is that, there is mismanagement of public funds as a result of leadership failure. In fact, every Nigerian needs a bailout. We should all call on God for divine intervention. Let everyone of us work for the interest of the nation. I also want to urge Buhari to tackle poverty. It is too alarming and disturbing-as it will encourage growth and sustenance of democracy in the nation. (p. 20).
\end{abstract}

An in-depth analysis of the prophetic message cited above could conveniently be said to be insightful as well as instructive. While it does not particularly possess predictive formulae or portend such powers, the prophet's message does not in any form contradict the concept of sola scriptura.

\title{
5. Recommendations
}

This work has unveiled the basis for "Sola scriptura and its impact on Christian prophetic making in Nigeria: its ambivalence" and the subsequent challenges the Sola scriptura in proliferation of churches in Nigeria and Africa per se. The present challenges seem to be tearing the unity of Nigerian Christians especially the Christian Association of Nigeria (CAN). Hence, this work recommends the following:

The need for the mainline churches and the African Initiated Churches (AICs) to maintain a balanced biblical interpretation following the principles of Jesus' ethical teachings,

The need for the ecclesiastical leadership to embrace doctrine of Sola scriptura as the pivot of Christian faith is necessary in respect of the doctrine of the Apostolic faith,

There is also the need for the various strands in the Christian communion to understand that in the spirit of one God, the Father, and one Lord, Jesus Christ or in the spirit of ecumenism, that extreme of any kind is not allowed,

No Christian group should have a particular theological statement of its own to fence it off from other Christian churches. This is in order to avoid false prophets, prophetesses, and false prophecies.

\section{Conclusion}

The centrality of the scripture in the practice of the Christian ministry cannot be underestimated. It is indispensably the basis for doctrinal formation, beliefs and practices of the Christian Church, especially the Protestants and Evangelicals. Any doctrine or practice that contradicts the scripture is deemed invalid and un-Christian. Nevertheless, it is obvious that the principle of sola scriptura has been adversely diluted especially among many Protestants and Pentecostals in the guise of prophecy and 'prophetism' in Nigeria. Many unsuspecting Nigerian Christians have fallen victims to these false prophets who, though profoundly make reference to the Bible, exploit the harsh economic conditions in the country, spiritual, material and emotional challenges of their clients to maneuver or swindle them. 
Predominantly, those who fall prey to the croaky and manipulative antics of these false prophets are found mostly among the desperate miracle seekers who are either looking for the "fruit of the womb" or the materialistic and prosperity pursuers who are prepared to pay the required price to get what they want. Often they are asked to sow seeds in form of substantial cash or other material deposits to the prophet or the man of God, as 'prerequisites for divine intervention.' While many of these prophets claim to have the scripture as the only principle of their prophetic ministry, evidences have proved several of them otherwise. Instances have been of some who were allegedly involved in shady practices such as diabolism, drug addiction, corruption, immorality, and other criminal tendencies. This is in utter disregard for the doctrine of sola scriptura.

However, the paradox of prophetic Christianity in Nigeria is its attraction for massive followership. Although ample evidences exist to confirm that many of these prophets do not have concrete and realistic solutions to the problems of their clients. They throng to them often in utter futility and disappointment. Ugwu (2015) observed that "it is unfortunate that we have a galaxy of blind and helpless men and women today that instead of crying to Jesus are busy crying to the crowd for help. The crowd can only pity them and offers them peanuts as alms but cannot have compassion on them. . . the crowd lacks the capability and ability to offer any enduring help" (p.24).

Understandably, and from the onset, the Catholics do not wholly accept this doctrine, adding that ecclesiastical authority and traditions are the bases for biblical interpretation. Nonetheless, the Catholics as well, are not spared from abuse and exploitation inherently prevalent with false 'prophecy.' The practice of Christian prophetic making in Nigeria is nonetheless expected to be nothing short of this conviction. It should be rooted in a deep personal conviction of the sufficiency of the scripture for human salvation and living. Again, the application of the sola scriptura belief in Nigerian Christianity has given rise to new religious movements such as aladura churches (prayer houses), Grace of God Mission, Deeper Life Bible Church of Nigeria, The Redeemed Christian Church of God, The Redeemed Evangelical Ministry, Church of God Mission, Mountain of Fire and Miracles Ministries and a host of other religious movements. Some of these movements are labeled "evangelical," "pentecostal," "charismatic," "fundamentalist" "holiness movement".

This conviction is made clearer during the Reformation, and is the basis of the doctrine of sola scriptura as held and taught by the Reformers. Many of them, such as John Calvin, John Wycliffe, Huss, Martin Luther, Huldreich or Ulrich Zwingli, and others were prepared to give convenience and even life, but not the word of God nor the convictions of their conscience therein (Edwards, 1998; Thomson, 1981). Atkinson (1982) and Fosdick (1952) cited Martin Luther's singlemindedness in relation to the scriptures. The Catholic Church threatened Luther with excommunication (and death) if he did not recant his convictions. Luther's reply was instructive of the doctrine of sola scriptura as he said,

I believe in neither popes nor councils alone, for it is perfectly well established that they have frequently erred, as well as contradicted themselves and might err again. Unless then I shall be convinced by the testimony of scripture, or by the clearest reasoning, I must be bound by those scriptures which have been brought forward by me, yes, my conscience have been taken captive by these words of God. I cannot revoke anything nor do I wish to; since to go against one's conscience is neither safe nor right. He added in German, 'I can no other! Here I stand! May God help me, Amen! (Atkinson, pp. 201-202; Fosdick, p. 80).

Nevertheless, the challenge of reconstructing this devalued authority necessarily belonging to the scripture becomes imminent, particularly in the Nigerian situation where the Christian faith and practice is turning to "big businesses. This paper attempts the recommendation of a few remedial doses for a return to this basic doctrinal stance of the Christian reformers.

First, the Church should ensure basic and balanced theological training for her clergy and teachers before commissioning them to minister. The fact that Nigeria is a highly religious competitive society is not a guarantee for abuse and excessiveness in the practice of prophetic Christianity in Nigeria. Although, Folayan (2015) maintains that Christians are radically rethinking the structure and context of theological education as they have received it at the hands of the missionary enterprise," It is, however, essential to the renewal of theological education that its uniqueness and distinctiveness is retrieved and maintained. This will ensure the formation of the people of God in the truth and wisdom of God for the purpose of personal renewal and meaningful participation in the fulfilment of the purpose of God in the Church and the Nigerian society.

Another important issue to be taken into account in responding to the increasing paradigm dimensions and changes in Christian prophetic making in Nigeria is the diversification of the education and professionalization of the leaders and teachers of Christian doctrines. This involves the specialization on specific areas of emphasis in Church ministry as is obtained in other humanities. Everyone cannot become a prophet. In Ephesians 4:11-13, the Apostle Paul viewed this strongly when he said, "It was he who gave some to be apostles, some to be prophets, some to be evangelists, and some to be pastors and teachers, to prepare God's people for works of service, so that the body of 
Christ may be built up until we all reach unity in the faith and in the knowledge of the Son of God and become mature, attaining to the whole measure of the fullness of Christ. Fake prophets and false prophecies would drastically reduce when each person is found committed to his own area.

A restructuring of the religious and theological mindset of the Nigerian Christians would be necessary, especially in relation to economic and material reliefs. The emphasis on prosperity, breakthrough, open doors and other such cliché have become dominant not only in the expressions, but also in the expectations of most Nigerian Christians. Unfortunately, the vulnerability of many miracle seekers has thus provided advantage for the practitioners of Christian prophetic making in Nigeria. However, a re-orientation achieved through conscious, consistent and genuine teaching of the true word of God would advance greatly the age-long truth of the doctrine of sola scriptura. Despite the misapplication and challenges, it is important to admit that sola scriptura rejects going to the extreme (that is being fanatical) in any matter of faith, while at the same time Christians should be guided by the fundamentals and comprehensiveness of the values of the scriptures.

\section{References}

Anderson, G. L. (2015). Pentecostal Hermeneutics. (Retrieved 29/08/15).http://agchurches.org/Sitefiles/Default/RSS/IValue/Resources/ Holy\%20Spirit/Articles/PentecostalHermeneuticsPt1.pdf

Atkinson, J. (1982). Martin Luther and the birth of Protestantism. London: Marshall Morgan \& Scott.

Edwards, D. (1998). Christianity: the first two thousand years. London: Cassell.

Encyclopedia Britannica, Literal Interpretation-Biblical Criticism, (Retrieved 29/08/15)

http://www.britannica.com/topic/literal-interpretation.

http://kingwatch.co.nz/Prophetic_Ministry/delivering_the_word.htm (Retrieved 25/08/15)

https://en.wikipedia.org/wiki/People_of_the_Book (Retrieved 24/08/15)

http://www.gotquestions.org/sola-scriptura.h̆tml (Retrieved 27/08/15)

Encyclopedia Britannica, Literal Interpretation-Biblical Criticism, (Retrieved 29/08/15)

http://www.britannica.com/topic/literal-interpretation

http://kingwatch.co.nz/Prophetic_Ministry/delivering_the_word.htm (Retrieved 25/08/15)

https://en.wikipedia.org/wiki/People_of_the_Book (Retrieved 24/08/15)

http://www. gotquestions.org/sola-scriptura.httml (Retrieved 27/08/15)

Ferguson, S. B. and Wright D. F. (Eds.) (1988). New Dictionary of Theology. Leicester: Inter Varsity Press.

Folayan, A. (2015). What is the Purpose of Theological Education?https://www.google.com.ng/search?q=need for TheologicalEducation \&ie=utf-8\&oe=utf-8\&aq=t\&rls=org

Fosdick, H. E. (1952). The Great Voices of the Reformation. New York: Random House Inc.

Geisler, N. L. and MacKenzie, R. E (2009). What is sola scriptura? http://www.equip.org/article/what-is-sola-scriptura/ (Retrieved 28/08/ 15)

Grudem, W. (1998). Systematic Theolog -An Introduction to Biblical Doctrine. Michigan: Zondervan Publishing House.

Harrison, R. K. (Ed.) (1985). The New Unger's Bible Dictionary. Chicago: Moody Press.

MacArthur, J. F. (2015). Proper Biblical Interpretation. (Retrieved 30/08/15). www.gty.org/resources/pdf/sermons/90-55

Mclain, M. (2015). 13 Keys to Receive and Release a Prophetic Word. http://www.charismamag.com/spirit/prophecy/17578-13-keys-toreceive-and-release-a-prophetic-word (Retrieved 27/08/15).

Nmah, P. E. (2009). Priests and Prophets: A Socio-Ethnic Reflection. Enugu: Rabboni.

Nmah, P. E. (2008). Religion and Society in Africa. Enugu: Rabboni.

Oladeji, O. (2015). Nigerian Presidential Election and the Shame of False Prophets. (Retrieved29/08/15) http://christianleavesonline. blogspot.com/2015/04/nigerias-presidential-election-and.htm.

Onunwa, U. (1990). Studies in Igbo Traditional Religion. Obosi: Pacific Publishers.

Onyeidu, S. O. (2004). Christianity and Society. Enugu: Easy-Quality.

Ramm, B. (1970).Protestant Biblical Interpretation: A Textbook of Hermeneutics. London: Baker Book House.

Silva, M. (1996). Foundations of Contemporary Interpretation. London: Apollos.

Sproul, R. C. (2005). Scripture Alone: The Evangelical Doctrine. London: P\&R Publishing.

Stronstad, R. (2015). Pentecostal Experience and Hermeneutics. (Retrieved 29/08/15) http://enrichmentjournal.ag.org/201004/201004_ 000_Pent_Herm.cfm

Thomson, A. (1981). Church history 3: AD 1500-1800, new movements, reform, rationalism, revolution. London: SPCK.

Ugwu, C. I. (2015). Overcoming the Crowd - The Pathway Enduring Greatness. Abuja: Premium Publishing House.

White, J. (2004). Scripture Alone. Illinois: Bethany House Publishers.

Yarchin, W. (2004). History of Biblical Interpretation: a Reader. Hendrickson:- 